\title{
ANALISIS BEBAN DAN STATUS PENCEMARAN BOD DAN COD DI KALI ASIN, SEMARANG
}

\author{
Lelim Yelli Kurnianti ${ }^{a^{*}}$, Haeruddin ${ }^{\text {, }}$, Arif Rahman ${ }^{a}$ \\ aProgram Studi Manajemen Sumberdaya Perairan, Departemen Sumberdaya Akuatik \\ Fakultas Perikanan dan Ilmu Kelautan, Universitas Diponegoro \\ J1. Prof. Soedarto, SH, Tembalang, Semarang, Jawa Tengah-50275, Telp/Fax +6224 7474698 \\ *Koresponden penulis: lelimyelli98@gmail.com
}

\begin{abstract}
Abstrak
Kali Asin merupakan sungai yang penting dalam sistem drainase di Semarang Utara. Sungai ini banyak dialiri oleh limbah domestik maupun limbah industri. Adanya masukkan dari limbah tersebut dapat menyebabkan penurunan kualitas air sungai yang ditandai dengan peningkatan konsentrasi Biological Oxygen Demand (BOD) dan Chemical Oxygen Demand (COD). Tujuan penelitian ini adalah menentukan beban pencemaran BOD dan COD serta mengkaji status pencemaran dengan menggunakan metode Indeks Pencemaran yang didasarkan pada Peraturan Pemerintah Nomor 82 Tahun 2001 kelas II. Sampling dilakukan pada 17 Desember 2019 sampai 28 Januari 2020. Sampling dilakukan sebanyak 3 kali yaitu setiap 3 minggu sekali. Materi yang digunakan pada penelitian ini adalah sampel air yang diambil dari tiga stasiun (muara, tengah pemukiman dan jauh dari pemukiman) yang didasarkan pada karakteristik wilayah, penggunaan lahan dan sumber cemaran. Metode penelitian menggunakan metode survei dengan teknik penentuan lokasi sampling menggunakan purposive sampling. Variabel kualitas air yang dianalisis yaitu temperatur, debit, $\mathrm{pH}, \mathrm{DO}, \mathrm{BOD}, \mathrm{COD}$. Berdasarkan hasil penelitian variabel tersebut sebagian besar tidak memenuhi baku mutu seperti variabel BOD dan COD. Hasil perhitungan beban pencemaran ditinjau dari variabel BOD dan COD secara berurutan didapatkan hasil rata-rata 952,54 kg/hari dan 3.425,86 kg/hari. Hasil perhitungan Indeks Pencemaran (IP) pada stasiun A, B, dan C secara berurutan sebesar 3,88; 3,78 dan 3,53. Tingkat pencemaran Kali Asin termasuk ke dalam tercemar ringan.
\end{abstract}

Kata kunci: Beban Pencemaran, BOD, COD, Indeks Pencemaran, Kali Asin

\begin{abstract}
Kali Asin is an important river for the drainage system in North Semarang. This river is often drained by domestic and industrial waste. The inclusion of these wastes can cause a decrease water quality marked by an increase Biological Oxygen Demand (BOD) and Chemical Oxygen Demand (COD) concentrations. The purpose of this study was to determine the load of BOD and COD pollution and assess the status of pollution using the Pollution Index Method based on Government Regulation Number 82 of 2001 class II. Sampling was carried on 17 December 2019-28 January 2020. Sampling was carried out three times, once in 3 weeks. The material used was water samples taken from three stations (estuary, middle of the settlement, and far from the settlement) based on regional characteristics, land use, and sources of pollution. The research method uses a survey method with the technique of determining the location of sampling using purposive sampling. Water quality variables analyzed were temperature, discharge, $\mathrm{pH}, \mathrm{DO}, \mathrm{BOD}$, COD. Based on the research results, these variables mostly do not meet the quality standards such as BOD and COD variables. The results of the calculation of pollution load in terms of BOD and COD variables obtained an average number of $952.54 \mathrm{~kg} /$ day and 3,425.86 kg/day. The results of the pollution index calculation at stations A, B, and C are $3.88 ; 3.78$ and 3.53. The level pollution of Kali Asin was categorized in mild contamination.
\end{abstract}

Keywords: Pollution Load, BOD, COD, Pollution Index, Kali Asin 


\section{PENDAHULUAN}

Air merupakan sesuatu hal yang sangat vital, karena semua makhluk hidup membutuhkan air untuk proses kehidupannya seperti untuk air minum, untuk keperluan irigasi bahkan untuk keperluan industri. Saat ini air menjadi permasalahan yang memerlukan perhatian khusus karena banyaknya ekosistem perairan seperti sungai yang tercemar. Bahan pencemar tersebut dapat berupa limbah domestik maupun limbah industri yang berasal dari aktivitas di sekitar sungai dan menyebabkan kualitas airnya menurun.

Sungai merupakan suatu ekosistem yang menjadi salah satu wadah tempat berkumpulnya air dari suatu kawasan. Baik buruknya kualitas air sungai akan berdampak kepada masyarakat itu sendiri, karena sungai sebagai sumber air untuk memenuhi kebutuhan sehari-hari telah tercermar oleh bahan pencemar. Pencemaran juga berdampak pada biota yang hidup di sungai karena air sungai telah mengalami perubahan baik secara fisika, kimia maupun biologi perairan [1].

Kali Asin merupakan suatu sungai yang terletak di antara Desa Kuningan dan Desa Bandarharjo, Kecamatan Semarang Utara, Kota Semarang. Sungai ini terletak di antara pemukiman warga. Di sekitar sungai ini terdapat industri pengasapan ikan. Sungai ini dijadikan oleh warga sekitar sungai sebagai tempat pembuangan limbah, baik limbah domestik seperti air detergen, sisa makanan, sampah plastik hingga limbah industri.

Kondisi fisik Kali Asin sendiri terdapat banyak sampah dan memiliki warna air coklat kehitaman. Selain itu juga terjadi pendangkalan akibat sedimentasi yang tinggi dan terdapat tumbuhnya eceng gondok pada beberapa titik di Kali Asin. Hal ini diindikasi telah terjadi pencemaran dari aktivitas manusia yang membuang limbah langsung ke Kali Asin. Aktivitas manusia sehari-hari yang terjadi di sekitar sungai dapat menyebabkan masuknya bahan pencemar. Masuknya bahan organik yang dihasilkan oleh kegiatan manusia ke perairan pada kondisi tertentu akan mengganggu kondisi existing perairan. Dimana kandungan bahan organik yang terlalu tinggi dapat menyebabkan eutrofikasi. Bahan-bahan organik ini akan didekomposisi oleh bakteri menggunakan oksigen terlarut untuk proses biokimia maupun proses biodegradasi. Hal ini akan mengakibatkan penurunan kadar oksigen terlarut dalam badan air [2].

Tingginya limbah domestik yang dibuang ke badan perairan dapat menyebabkan kandungan bahan organik pada perairan meningkat. Meningkatnya kandungan bahan organik pada perairan akan berpengaruh terhadap penurunan kualitas air. Salah satunya yaitu terjadi peningkatan konsentrasi BOD dan COD di perairan. Peningkatan konsentrasi BOD dan COD ini akan berpengaruh terhadap kehidupan biota dalam perairan. [3] Bahan organik maupun anorganik yang berasal dari aktivitas manusia di sekitar sungai ataupun dari limbah industri dapat meningkatkan kandungan BOD maupun COD di perairan. Tingginya kandungan BOD atau COD di perairan dapat menurunkan konsentrasi oksigen terlarut (DO), sehingga dapat mempengaruhi penurunan kualitas air dan produktifitas sumberdaya perairan. Melihat hal tersebut, maka perlu dilakukan penelitian dengan tujuan untuk menentukan beban pencemaran BOD dan COD serta mengkaji status pencemaran di Kali Asin, Semarang.

\section{METODE}

\section{Materi}

Materi yang digunakan dalam penelitian ini yaitu sampel air Kali Asin, Semarang yang digunakan sebagai analisis beban pencemaran dan mengkaji status pencemaran menggunakan variabel utama BOD (Biological Oxygen Demand) dan COD (Chemical Oxygen Demand) serta variabel pendukung DO (Dissolved Oxygen) yang diukur secara insitu dengan metode Winkler, $\mathrm{pH}$, temperatur dan debit dengan menggunakan line transect. Analisis variabel BOD dan COD dilakukan secara exsitu menggunakan Standar Nasional Indonesia 6989:72:2009 dan 6989:2:2004.

\section{Metode Penelitian}

Penelitian ini menggunakan metode survei, merupakan suatu metode yang digunakan untuk mendapatkan keterangan yang jelas dan baik 
terhadap suatu persoalan tertentu dan dalam suatu daerah tertentu dengan cara pengamatan atau penyelidikan secara kritis [4]. Data yang dikumpulkan dalam penelitian ini yaitu konsentrasi BOD, COD, DO, $\mathrm{pH}$, temperatur, debit dan kemudian dianalisis secara kuantitatif untuk menghitung beban pencemaran dan status pencemaran air sesuai dengan rumus yang terdapat pada Peraturan Menteri Negara Lingkungan Hidup Nomor 1 Tahun 2010 dan Keputusan Menteri Lingkungan Hidup Nomor 115 Tahun 2003.

\section{Penentuan Lokasi Pengambilan Sampel}

Penentuan lokasi pengambilan sampel dilakukan berdasarkan pada karakteristik wilayah, penggunaan lahan dan sumber cemaran. Metode yang digunakan dalam penentuan lokasi pengambilan sampel yaitu metode purposive sampling. [5] Metode purposive sampling merupakan teknik pengambilan sampel sumber data dengan pertimbangan tertentu. Pertimbangan dalam penentuan stasiun pada penelitian ini yaitu dengan melihat karakteristik lingkungan,

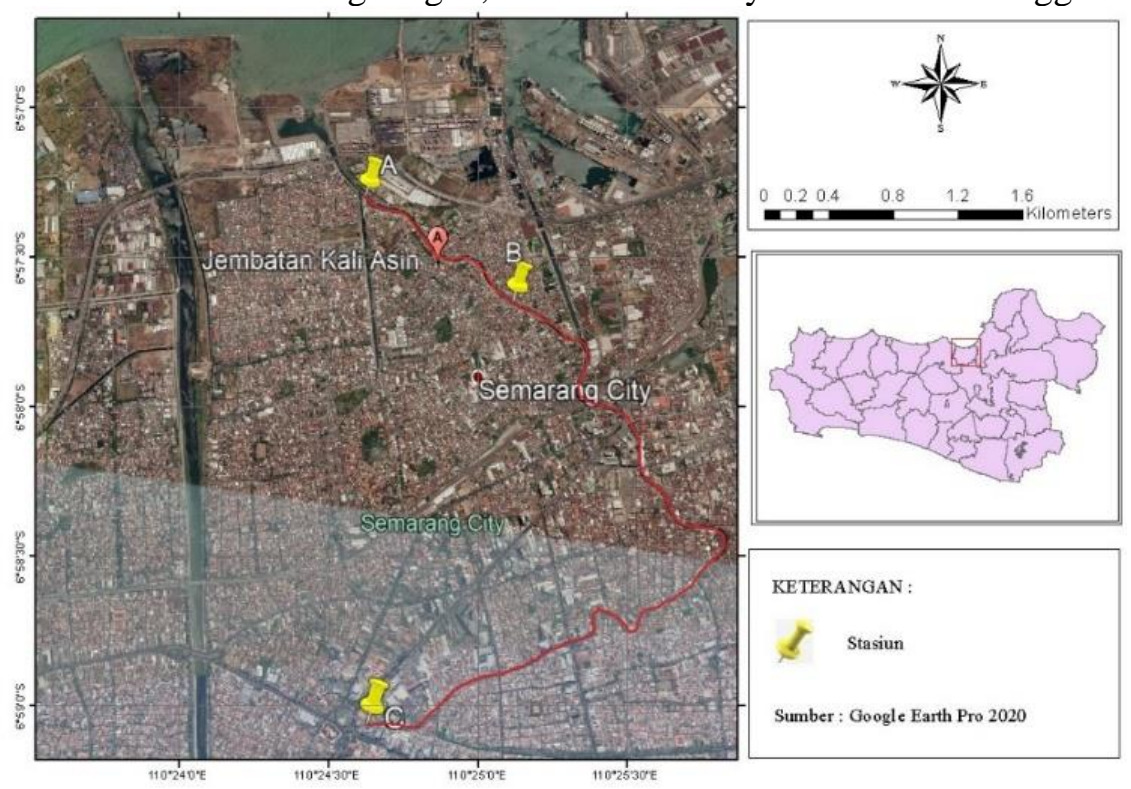

Gambar 1. Peta Lokasi Penelitian

\section{Analisis Beban Pencemaran}

\section{Perhitungan beban pencemaran dapat dihitung dengan perkalian antara variabel debit dengan}

penggunaan lahan dan sumber cemaran pada setiap stasiun, karena setiap stasiun memiliki karakteristik yang berbeda-beda.

Pengambilan sampel dilakukan pada 3 stasiun di Kali Asin (A, B, C) yang disajikan pada

Gambar 1. Pengambilan sampel pada stasiun A dilakukan pada muara Kali Asin, dimana pada umumnya di muara terdapat paling banyak limbah yang bersumber dari aliran mulai dari hulu hingga menuju hilir sungai dan di sekitar muara Kali Asin juga terdapat industri pengasapan ikan. Pengambilan sampel pada stasiun B dilakukan pada tengah-tengah aliran Kali Asin (dekat dengan pemukiman warga), dimana di lokasi tersebut diindikasi sudah tercemar oleh limbah domestik. Pengambilan sampel pada stasiun C dilakukan pada aliran sungai yang jauh dari pemukiman warga, dimana lokasi tersebut sedikit pencemaran yang masuk. Setiap stasiun dilakukan pengambilan sampel pada 3 titik (A1,A2,A3/ B1,B2,B3/ $\mathrm{C} 1, \mathrm{C} 2, \mathrm{C} 3$ ) yaitu pada tepi, tengah dan tepi sungai. Pengambilan sampel dilakukan 3 kali (P1, P2, P3) pada setiap stasiun dan dilakukan pada waktu yang berbeda yaitu selama 3 minggu sekali.

konsentrasi setiap variabel yang dianalisis yaitu BOD dan COD. Menurut Peraturan Menteri Negara Lingkungan Hidup Nomor 1 Tahun 2010 bahwa 
rumus perhitungan beban pencemaran adalah sebagai berikut:

$$
\mathrm{BPs}=\mathrm{Qs} \times \mathrm{Cs}(\mathrm{j}) \times \mathrm{f}
$$

$\mathrm{Cs}(\mathrm{j})=$ Konsentrasi unsur pencemar $\mathrm{j}(\mathrm{mg} / \mathrm{L})$

$\mathrm{f} \quad=$ Faktor konversi menjadi $\mathrm{kg} / \mathrm{hari}$

$$
\begin{aligned}
& =\frac{1.000 \text { liter }}{1 \mathrm{~m}^{3}} \times \frac{86.400 \text { detik }}{1 \text { hari }} \times \frac{1 \mathrm{~kg}}{1.000 .000 \mathrm{mg}} \\
& =\frac{86.400 .000}{1.000 .000} \\
& =86,4 \mathrm{~kg} / \text { hari }
\end{aligned}
$$

\section{Analisis Status Pencemaran Air}

Analisis status pencemaran air dapat dilakukan dengan menggunakan metode Indeks Pencemaran. Variabel yang digunakan untuk mengkuantifikasi status pencemaran air pada penelitian ini adalah BOD, COD, DO, $\mathrm{pH}$ dan temperatur. Menurut Keputusan Menteri Lingkungan Hidup Nomor 115 Tahun 2003 bahwa rumus Indeks Pencemaran untuk menentukan tingkat pencemaran suatu badan perairan adalah sebagai berikut:
Keterangan:

BPs = Beban pencemaran sungai $(\mathrm{kg} / \mathrm{hari})$

Qs = Debit air sungai ( $\mathrm{m}^{3} /$ detik)

$$
P I_{j}=\sqrt{\frac{\left(C_{i} / L_{i j}\right)_{M}^{2}+\left(C_{i} / L_{i j}\right)_{R}^{2}}{2}}
$$

Keterangan:

$$
\begin{array}{ll}
\mathrm{PI}_{\mathrm{j}} & =\text { Indeks pencemaran bagi } \\
& \text { peruntukan }(\mathrm{j}) \\
\mathrm{C}_{\mathrm{i}} & \text { = Konsentrasi parameter kualitas } \\
& \text { air (i) dari hasil analisis } \\
\mathrm{L}_{\mathrm{ij}} & =\text { Konsentrasi parameter kualitas } \\
& \text { air dalam baku mutu peruntukan } \\
& \text { air }(\mathrm{j}) \\
\left(\mathrm{C}_{\mathrm{i}} / \mathrm{L}_{\mathrm{ij}}\right)_{\mathrm{M}} & =\text { Nilai } \mathrm{C}_{\mathrm{i}} / \mathrm{L}_{\mathrm{ij}} \text { maksimum } \\
\left(\mathrm{C}_{\mathrm{i}} / \mathrm{L}_{\mathrm{ij}}\right)_{\mathrm{R}} \quad & =\text { Nilai } \mathrm{C}_{\mathrm{i}} / \mathrm{L}_{\mathrm{ij}} \text { rata-rata }
\end{array}
$$

\begin{tabular}{|c|c|c|}
\hline Stasiun & Koordinat & Deskripsi \\
\hline A & $\begin{array}{l}\text { LS: } 6^{0} 57^{\prime} 20.33^{\prime \prime} \\
\text { BT: } 110^{\circ} 24^{\prime} 36.61^{\prime \prime}\end{array}$ & $\begin{array}{l}\text { Stasiun A berada di antara Desa Kuningan dan Desa Bandarharjo, Semarang } \\
\text { Utara. Stasiun ini merupakan muara dari Kali Asin. Terdapat pemukiman } \\
\text { penduduk serta industri pengasapan ikan di sepanjang muara. Kondisi perairan } \\
\text { sangat keruh, terdapat banyak sampah serta tumbuhan eceng gondok dan } \\
\text { sedimentasi di tepi sungai. }\end{array}$ \\
\hline B & $\begin{array}{l}\text { LS: } 6^{0} 57^{\prime} 43.50^{\prime}, \\
\text { BT: } 110^{\circ} 25^{\prime} 7.44^{\prime \prime}\end{array}$ & $\begin{array}{l}\text { Stasiun B berada di antara Desa Kuningan dan Desa Bandarharjo, Semarang Utara. } \\
\text { Jarak antara stasiun A dan B yaitu } 1,28 \mathrm{~km} \text {. Stasiun ini berada di tengah-tengah } \\
\text { pemukiman warga. Terdapat banyak saluran pembuangan air yang masuk ke } \\
\text { dalam sungai.Selain itu terdapat perahu penyebrangan di dekat titik pengambilan } \\
\text { sampel air. Kondisi perairan lumayan keruh dan terdapat banyak sampah serta } \\
\text { eceng gondok dan sedimentasi di tepi sungai. }\end{array}$ \\
\hline $\mathrm{C}$ & $\begin{array}{l}\text { LS: } 6^{0} 59^{\prime} 4.27^{\prime \prime} \\
\text { BT: } 110^{\circ} 24^{\prime} 38.38^{\prime \prime}\end{array}$ & $\begin{array}{l}\text { Stasiun } \mathrm{C} \text { berada di Jl. Inspeksi, Semarang Tengah. Jarak antara stasiun B dan C } \\
\text { yaitu } 4,89 \mathrm{~km} \text {. Stasiun ini jauh dari pemukiman warga. Kondisi perairan bersih. }\end{array}$ \\
\hline
\end{tabular}

Tabel 1. Klasifikasi Kualitas Air

\begin{tabular}{ll}
\hline Nilai PI & Keterangan \\
\hline $0 \leq \mathrm{PI}_{\mathrm{j}} \leq 1,0$ & Memenuhi baku mutu (kondisi \\
$1,0<\mathrm{PI}_{\mathrm{j}} \leq 5,0$ & baik) \\
$5,0<\mathrm{PI}_{\mathrm{j}} \leq 10$ & Cemar ringan \\
$\mathrm{PI}_{\mathrm{j}}>10$ & Cemar sedang \\
\hline
\end{tabular}

HASIL DAN PEMBAHASAN

\section{Lokasi Penelitian}

Lokasi pengukuran kualitas air dan pengambilan sampel air Kali Asin dilakukan pada tiga stasiun dengan karakteristik masing-masing yang dijelaskan pada Tabel 2 .

Tabel 2. Koordinat dan Deskripsi Lokasi Pengambilan Sampel Air Kali Asin 


\section{Kualitas Air di Kali Asin}

Hasil pengukuran parameter kualitas air di Kali Asin disajikan pada Tabel 3. Nilai temperatur yang didapatkan fluktuatif berkisar antara $29-34^{\circ} \mathrm{C}$. Debit di stasiun A lebih tinggi dibandingkan dengan yang lain. Hal ini dikarenakan pada saat pengukuran sedang dilakukan pemompaan air yang ada di muara untuk dialirkan ke laut. Nilai $\mathrm{pH}$ yang didapatkan fluktuatif berkisar antara 6,07- 6,24, dimana masih berada diantara rentang baku mutu yang telah ditetapkan (6-9). Sebagian besar konsentrasi DO telah melebihi baku mutu kecuali pada stasiun C-P1 sebesar 4,39 mg/L. Konsentrasi BOD dan COD tertinggi terdapat pada stasiun AP3 sebesar 20,69 mg/L dan 82,53 $\mathrm{mg} / \mathrm{L}$. Konsentrasi BOD dan COD terendah yaitu pada stasiun B-P1 sebesar 9,61 mg/L dan 29,37 mg/L. Hasil pengukuran BOD dan COD untuk semua stasiun telah melebihi baku mutu yang telah ditetapkan yaitu $3 \mathrm{mg} / \mathrm{L}$ dan $25 \mathrm{mg} / \mathrm{L}$.

Tabel 3. Kualitas Air di Kali Asin

\begin{tabular}{|c|c|c|c|c|c|c|c|c|c|c|}
\hline \multirow{3}{*}{ Parameter } & \multicolumn{9}{|c|}{ Titik Sampling } & \multirow{3}{*}{$\begin{array}{c}\text { Baku } \\
\text { Mutu } \\
\text { Kelas II }\end{array}$} \\
\hline & \multicolumn{3}{|c|}{$\mathbf{A}$} & \multicolumn{3}{|c|}{ B } & \multicolumn{3}{|c|}{$\mathbf{C}$} & \\
\hline & P1 & $\mathbf{P 2}$ & $\mathbf{P 3}$ & P1 & $\mathbf{P 2}$ & P3 & P1 & $\mathbf{P 2}$ & $\mathbf{P 3}$ & \\
\hline \multicolumn{11}{|l|}{ Fisika } \\
\hline $\begin{array}{l}\text { Temperatur } \\
\left({ }^{\circ} \mathrm{C}\right)\end{array}$ & 32 & 31 & 33 & 34 & 29 & 32 & 29 & 29 & 30 & Deviasi 3 \\
\hline Debit $\left(\mathrm{m}^{3} / \mathrm{s}\right)$ & 1,16 & 1,25 & 1,13 & 1,10 & 0,99 & 0,77 & 0,47 & 0,14 & 0,05 & \# \\
\hline \multicolumn{11}{|l|}{ Kimia } \\
\hline $\mathrm{pH}$ & 6,07 & 6,13 & 6,24 & 6,24 & 6,15 & 6,11 & 6,12 & 6,19 & 6,14 & $6-9$ \\
\hline $\mathrm{DO}(\mathrm{mg} / \mathrm{L})$ & 0,99 & 1,51 & 0,13 & 1,01 & 1,57 & 1,03 & 4,39 & 1,69 & 2,12 & 4 \\
\hline $\begin{array}{l}\text { BOD } \\
(\mathrm{mg} / \mathrm{L})\end{array}$ & $10,25 *$ & $13,34 *$ & $20,69^{*}$ & $9,61 *$ & $15,09 *$ & $19,60 *$ & $16,54 *$ & $14,88^{*}$ & $14,66^{*}$ & 3 \\
\hline $\begin{array}{l}\text { COD } \\
(\mathrm{mg} / \mathrm{L})\end{array}$ & $33,05 *$ & $49,37 *$ & $82,53 *$ & $29,37 *$ & $36,21^{*}$ & $82,00 *$ & $53,05^{*}$ & $34,11^{*}$ & $50,95^{*}$ & 25 \\
\hline
\end{tabular}

Keterangan:

(*): telah melebihi baku mutu

(\#): tidak dipersyaratkan dalam baku mutu

Tabel 4. Hasil Perhitungan Beban Pencemaran di Kali Asin

\begin{tabular}{|c|c|c|c|c|c|}
\hline \multirow{2}{*}{ Stasiun } & \multirow{2}{*}{ Pengulangan } & \multirow{2}{*}{ Debit $\mathbf{m}^{3} / \mathrm{s}$} & \multirow{2}{*}{$\begin{array}{c}\text { Debit } \\
\text { m³ }^{3} / \mathbf{h a r i}\end{array}$} & \multicolumn{2}{|c|}{ Beban Pencemaran (kg/hari) } \\
\hline & & & & BOD & COD \\
\hline \multirow{3}{*}{ A } & $\mathrm{P} 1$ & 1,16 & 100.224 & $1.027,30$ & $3.312,40$ \\
\hline & P2 & 1,25 & 108.000 & $1.440,72$ & $5.331,96$ \\
\hline & P3 & 1,13 & 97.632 & $2.020,01$ & $8.057,57$ \\
\hline \multirow{3}{*}{ B } & $\mathrm{P} 1$ & 1,10 & 95.040 & 913,33 & $2.791,32$ \\
\hline & $\mathrm{P} 2$ & 0,99 & 85.536 & $1.290,74$ & $3.097,26$ \\
\hline & P3 & 0,77 & 66.528 & $1.303,95$ & $5.455,30$ \\
\hline \multirow{3}{*}{$\mathrm{C}$} & $\mathrm{P} 1$ & 0,47 & 40.608 & 671,66 & $2.154,25$ \\
\hline & $\mathrm{P} 2$ & 0,14 & 12.096 & 179,99 & 412,59 \\
\hline & P3 & 0,05 & 4.320 & 63,33 & 220,10 \\
\hline \multicolumn{2}{|c|}{ Rata-rata } & - & - & 952,54 & $3.425,86$ \\
\hline
\end{tabular}




\section{Beban Pencemaran di Kali Asin}

Berdasarkan hasil perhitungan beban pencemaran di Kali Asin yang disajikan pada Tabel 4, variabel COD memiliki beban pencemaran tertinggi dibandingkan variabel lainnya, yaitu sebesar 3.425,86 kg/hari. Hal tersebut menunjukkan bahwa kegiatan yang dapat meningkatkan COD masih tinggi seperti: pembuangan air sisa cucian, sisa deterjen, air sisa cucian industri perikanan, sisa makanan. [6] Penurunan kualitas air sungai salah satunya disebabkan oleh limbah domestik. Sumbangan beban pencemaran yang berasal dari limbah domestik paling tinggi yaitu bahan organik seperti kotoran hewan dan manusia. Jenis limbah domestik yang lain yaitu limbah anorganik yang bersumber dari plastik, penggunaan deterjen, shampo, cairan pemutih, pewangi dan bahan kimia lainnya.

Beban pencemaran BOD dan COD tertinggi terdapat pada stasiun A-P3 sebesar 2.020,01 $\mathrm{kg} / \mathrm{hari}$ dan $8.057,57 \mathrm{~kg} / \mathrm{hari}$. Tingginya beban pencemaran di stasiun A dikarenakan stasiun A merupakan muara Kali Asin, dimana sebagai tempat mengumpulnya limbah yang berasal dari hulu sungai. [7] Nilai beban pencemaran terus meningkat dari hulu ke hilir. Nilai beban pencemar yang tinggi dikarenakan adanya aktivitas industri maupun domestik yang membuang limbah ke sungai. Adanya sumber pencemar di sekitar sungai yang menyumbang beban cemaran cukup tinggi, merupakan salah satu indikasi adanya penurunan kualitas lingkungan di sekitar sungai dan adanya perubahan tata guna lahan. Selain merupakan muara Kali Asin yang menjadi sumber pencemaran tertinggi, di sekitar stasiun A juga terdapat pemukiman dan industri pengasapan ikan yang mengalirkan limbah hasil cucian ikan langsung ke badan perairan Kali Asin, yang menjadi penyumbang beban pencemaran pada sungai. [8] Limbah cair perikanan yang langsung dibuang ke sungai dapat menyebabkan pencemaran seperti dapat menumbuhkan tumbuhan pengganggu seperti eceng gondok, muncul toksisitas terhadap kehidupan air, menurunkan kadar oksigen terlarut di perairan, membahayakan masyarakat serta dapat menimbulkan bau yang mengganggu.

Tingginya beban pencemaran di stasiun A dapat mengakibatkan rendahnya konsentrasi oksigen terlarut yang dapat dilihat pada Tabel 3, dimana konsentrasi oksigen telarut (DO) pada stasiun A memiliki konsentrasi paling kecil dibandingkan stasiun lainnya. [9] Perairan yang memiliki konsentrasi BOD yang tinggi mengindikasi bahwa perairan tersebut tercemar. [3] Tingginya konsentrasi BOD dapat menurunkan konsentrasi DO, sehingga dapat mempengaruhi penurunan kualitas air dan produktifitas sumberdaya perairan. [10] Pada umumnya DO di suatu perairan bersifat fluktuatif setiap waktunya. Konsentrasi DO pada perairan sungai semakin ke hilir akan semakin turun hingga tidak memenuhi baku mutu yang sudah ditetapkan. [11] DO memegang peranan penting sebagai indikator kualitas air, karena DO berperan dalam proses oksidasi serta reduksi bahan organik dan anorganik. Karena proses oksidasi dan reduksi ini, maka peranan DO sangat penting untuk membantu mengurangi tingginya beban pencemaran di perairan

Rendahnya konsentrasi DO pada stasiun A secara langsung dapat mempengaruhi kehidupan biota air di dalamnya, karena oksigen sangat dibutuhkan ikan untuk proses respirasi, pertumbuhan serta bereproduksi. [12] Sebagian besar ikan yang mati di perairan tercemar bukan karena daya racun bahan buangan, melainkan diakibatkan karena kekurangan oksigen dalam perairan akibat digunakan untuk degradasi bahan organik oleh mikroorganisme. Kebutuhan oksigen pada ikan yang hidup di perairan tawar tropis \pm 5 mg/L. [13] Konsentrasi DO rendah mengakibatkan kondisi sungai dalam keadaan anaerob. Keadaan anaerob ini dapat menyebabkan penguraian secara anaerobik yaitu zat organik akan terurai menjadi $\mathrm{CO}_{2}$ dan gas metan, sedangkan senyawa nitrogen akan menjadi amoniak dan senyawa sulfur akan diubah menjadi asam sulfida $\left(\mathrm{H}_{2} \mathrm{~S}\right)$, sehingga air akan menjadi berwarna hitam dan bau.

Beban pencemaran BOD dan COD terendah terdapat pada stasiun C-P3 sebesar 63,33 kg/hari dan $220,10 \mathrm{~kg} / \mathrm{hari}$. Hal ini dikarenakan stasiun C terletak jauh dari pemukiman, sehingga pencemaran yang masuk ke dalam sungai lebih sedikit. [14] Beberapa faktor yang mempengaruhi kontribusi beban pencemaran sungai yang berasal dari kegiatan rumah tangga (domestik) yaitu jumlah penduduk yang tinggal di sepanjang sungai serta jarak antara pemukiman penduduk dengan sungai. Dapat diasumsikan bahwa semakin dekat 
pemukiman penduduk dengan sungai, maka semakin besar pula kontribusi limbah domestik dalam menyumbang beban pencemaran sungai. Karena sebagian penduduk yang tinggal di dekat sungai akan membuang limbahnya secara langsung ke sungai.

\section{Status Pencemaran di Kali Asin}

Hasil perhitungan indeks pencemaran Kali Asin disajikan pada Tabel 5.

Tabel 5. Status Pencemaran di Kali Asin

\begin{tabular}{ccc}
\hline Stasiun & Nilai IP & Keterangan \\
\hline A & 3,88 & Tercemar ringan \\
B & 3,78 & Tercemar ringan \\
C & 3,53 & Tercemar ringan \\
\hline
\end{tabular}

Indeks pencemaran yang diperoleh pada stasiun A adalah 3,88, tergolong ke dalam tercemar ringan dan merupakan indeks pencemaran tertinggi dari ketiga stasiun. Pencemaran yang terjadi di stasiun A disebabkan karena adanya penumpukan pencemaran di stasiun A yang berasal dari stasiun B dan stasiun C. Selain itu, juga adanya industri pengasapan ikan di sepanjang muara sungai yang membuang hasil cucian ikan langsung ke sungai. [15] Bahan pencemaran yang masuk ke dalam sungai akan dibawa oleh air sungai mulai dari hulu ke hilir dan terakumulasi di muara sungai, sehingga berbagai bahan pencemar tersebut memiliki konsentrasi yang lebih tinggi di muara sungai dibandingkan dengan bagian sungai lainnya. [16] Indeks pencemaran tertinggi yaitu terletak pada stasiun yang dekat dengan daratan seperti muara sungai. Muara sungai ini sangat dipengaruhi oleh aktivitas manusia seperti kegiatan rumah tangga maupun industri yang dapat mengakibatkan daerah tersebut rentan terhadap perubahan kondisi lingkungan.

Peningkatan status pencemaran pada stasiun A terjadi seiring dengan tingginya nilai beban pencemaran di stasiun A yang disajikan pada Tabel 4. Hal ini juga dibuktikan dengan tingginya konsentrasi BOD dan COD yang mengakibatkan rendahnya konsentrasi DO di dalam air. Rendahnya oksigen terlarut juga dipengaruhi oleh tingginya temperatur air pada stasiun A yang disajikan di Tabel 3. Meningkatnya temperatur akan menyebabkan meningkatnya proses dekomposisi bahan organik oleh mikroba di perairan. Temperatur dapat mempengaruhi reaksi kimia serta biologi yang terjadi di suatu perairan. Terjadinya kenaikan temperatur dapat menyebabkan penurunan kadar oksigen terlarut, peningkatan reaksi kimia dan terganggunya kehidupan biota air. Selain itu juga dapat meningkatkan dekomposisi bahan organik oleh mikroorganisme [10]. Penyebaran suhu di suatu perairan oleh arus air serta turbulensi di daerah hulu, tengah dan hilir sangatlah berbeda. Intensitas cahaya matahari, semakin ke hilir semakin banyak, sehingga pertukaran antara air dan udara semakin ke hilir semakin besar dan terjadi peningkatan panas [11].

Indeks pencemaran yang diperoleh pada stasiun B adalah 3,78, tergolong ke dalam tercemar ringan. Pencemaran yang terjadi di stasiun B disebabkan oleh limbah rumah tangga yang dibuang langsung ke perairan. Padatnya penduduk menunjukkan semakin banyaknya aktivitas masyarakat yang menghasilkan limbah seperti: sampah plastik, air cucian, limbah kertas, maupun sisa makanan. Limbah rumah tangga baik yang organik maupun non-organik ini dapat menurunkan nilai kualitas air. [9] Peningkatan jumlah penduduk di suatu daerah akan mengakibatkan perubahan pola konsumsi masyarakat yang cukup tinggi dari tahun ke tahun, dengan luas lahan yang tetap akan mengakibatkan tekanan lingkungan semakin berat. Meningkatnya aktivitas manusia dalam memenuhi kebutuhan hidupnya, akan menghasilkan limbah yang memberi sumbangan pada penurunan kualitas air sungai.

Meningkatnya pencemaran di stasiun B juga diakibatkan karena adanya kegiatan penyebrangan menggunakan kapal oleh warga. Pergerakan kapal dapat menyebabkan teraduknya sedimen dan meningkatkan kekeruhan. [17] Kekeruhan menggambarkan sifat optik air yang ditentukan berdasarkan banyaknya cahaya yang diserap dan dipancarkan oleh bahan-bahan yang terdapat di dalam air. Kekeruhan disebabkan oleh bahan organik maupun anorganik yang tersuspensi dan terlarut misalnya lumpur dan pasir atau organisme. Kekeruhan yang tinggi akan mempengaruhi proses penetrasi cahaya matahari dan menghambat proses fotosintesis, sehingga akan menyebabkan berkurangnya oksigen di perairan dan produktifitas di perairan akan berkurang pula. Hal ini terbukti 
bahwa konsentrasi oksigen terlarut pada stasiun B rendah dan dapat dilihat pada Tabel 3.

Indeks pencemaran yang diperoleh pada stasiun $\mathrm{C}$ adalah 3,53 yang tergolong ke dalam tercemar ringan. Hal tersebut menunjukkan bahwa masih dapat dimanfaatkan untuk prasarana/sarana rekreasi air, pembudidayaan ikan air tawar, peternakan, air untuk mengairi tanaman. Pencemaran yang terjadi di stasiun $\mathrm{C}$ ini memiliki nilai paling kecil dibandingkan dengan stasiun yang lain. Hal ini dikarenakan stasiun $\mathrm{C}$ terletak

\section{Rasio BOD/COD}

Hasil analisis rasio BOD/COD Kali Asin disajikan pada Tabel 6. Rasio BOD/COD yang diperoleh pada stasiun $\mathrm{A}, \mathrm{B}$ dan $\mathrm{C}$ berturut-turut adalah 0,$28 ; 0,33$ dan 0,35 . Rasio BOD/COD yang diperoleh pada ketiga stasiun ini menunjukkan bahwa bahan-bahan pencemar organik yang ada di stasiun A, B dan C bersifat biodegradable (0,2 $0,5)$ yang berarti bahwa bahan-bahan pencemar yang masuk ke dalam Kali Asin ini mudah terurai. Rasio BOD/COD digunakan sebagai indikator untuk dampak output dari zat organik yang berada pada air, limbah, lindi, kompos dan materialmaterial lain yang serupa, yang terjadi di lingkungan, baik di lingkungan alam maupun di lingkungan buatan manusia. Rasio BOD/COD ini terbagi menjadi tiga zona di dalam perairan, dimana ketiga zona tersebut adalah zona stabil, zona biodegradable dan zona toksik. Rasio $\mathrm{BOD} / \mathrm{COD}$ di dalam range biodegradable $(0,2$ $0,5)$ ini baik untuk budidaya serta proses biologis. Nilai rasio BOD/COD ini mengindikasikan biodegradibilitas dari air buangan, dimana semakin tinggi rasio, biodegradibilitas air buangan menjadi semakin rendah [18]. jauh dari pemukiman sehingga limbah yang masuk ke sungai lebih sedikit. Hal ini juga di dukung dengan hasil pengukuran oksigen terlarut pada stasiun $\mathrm{C}$ yang memiliki konsentrasi paling tinggi dibandingkan dengan stasiun yang lain. Jika dilihat dari hasil analisis BOD/COD yang disajikan pada Tabel 6, pada stasiun $\mathrm{C}$ memiliki rasio $\mathrm{BOD} / \mathrm{COD}$ tertinggi yaitu 0,35 , yang berarti bahwa bahan pencemaran yang masuk di stasiun $\mathrm{C}$ bersifat mudah terurai.

\section{KESIMPULAN}

Kesimpulan yang dapat diambil dari hasil penelitian yang telah dilakukan di daerah aliran Kali Asin, Semarang adalah rata-rata beban pencemaran yang masuk berdasarkan variabel BOD dan COD sebesar 952,54 kg/hari dan $3.425,86 \mathrm{~kg} / \mathrm{hari}$. Tingkat pencemaran Kali Asin berdasarkan dari perhitungan Indeks Pencemaran (IP) dengan menggunakan 5 variabel yaitu temperatur, $\mathrm{pH}, \mathrm{DO}, \mathrm{BOD}$ dan COD sebesar 3,533,88 yang termasuk dalam kelas tercemar ringan.

\section{UCAPAN TERIMA KASIH}

Penulis mengucapkan terima kasih kepada Allah SWT yang telah memberikan rahmat dan hidayah-Nya sehingga penulis dapat menyelesaikan penelitian ini. Terima kasih kepada Dr. Ir. Bambang Sulardiono, M.Si dan Churun A'in, S.Pi., M.Si sebagai dosen penguji, serta kepada Dr. Diah Ayuningrum, S.Pd., M.Si sebagai pembimbing dalam Scientific Writing Class (SWC) dan seluruh pihak yang membantu dalam proses penyusunan dan memberikan semangat, kritik, dan saran untuk terselesaikannya penelitian ini.

Tabel 6. Rasio BOD/COD

\begin{tabular}{|c|c|c|c|c|c|c|c|c|c|}
\hline \multirow[b]{2}{*}{ Pengulangan } & \multicolumn{3}{|c|}{$\mathbf{A}$} & \multicolumn{3}{|c|}{ B } & \multicolumn{3}{|c|}{$\mathrm{C}$} \\
\hline & BOD & COD & $\begin{array}{c}\text { Rasio } \\
\text { BOD/COD }\end{array}$ & BOD & COD & $\begin{array}{c}\text { Rasio } \\
\text { BOD/COD }\end{array}$ & BOD & COD & $\begin{array}{c}\text { Rasio } \\
\text { BOD/COD }\end{array}$ \\
\hline P1 & 10,25 & 33,05 & 0,31 & 9,61 & 29,37 & 0,33 & 16,54 & 53,05 & 0,31 \\
\hline P2 & 13,34 & 49,37 & 0,27 & 15,09 & 36,21 & 0,42 & 14,88 & 34,11 & 0,44 \\
\hline P3 & 20,69 & 82,53 & 0,25 & 19,60 & 82,00 & 0,24 & 14,66 & 50,95 & 0,29 \\
\hline Rata-rata & & & 0,28 & & & 0,33 & & & 0,35 \\
\hline
\end{tabular}




\section{DAFTAR PUSTAKA}

[1] Yogafanny, E. 2015. Pengaruh Aktivitas Warga di Sempadan Sungai terhadap Kualitas Air Sungai Winongo. Jurnal Sains dan Teknologi Lingkungan, 7(1): 41-50.

[2] Alfionita, A. N. A., Patang dan E. S. Kaseng. 2019. Pengaruh Eutrofikasi Terhadap Kualitas Air Sungai Jeneberang. Jurnal Pendidikan Teknologi Pertanian, 5(1): 9-23.

[3] Supriyantini, E., R. A. T. Nuraini dan A. P. Fadmawati. 2017. Studi Kandungan Bahan Organik pada Beberapa Muara Sungai di Kawasan Ekosistem Mangrove, di Wilayah Pesisir Pantai Utara Kota Semarang, Jawa Tengah. Buletin Oseanografi Marina, 6(1): 29-38.

[4] Prasti, A dan Widyastuti. 2015. Kondisi Fisik dan Kualitas Permukiman Kawasan Pesisir Kecamatan Baolan Kabupaten Tolitoli. Jurnal GeoTadulako, 3(5): 71-83.

[5] Suryanti, S. Rudiyanti dan S. Sumartini. 2013. Kualitas Perairan Sungai Seketak Semarang Berdasarkan Komposisi dan Kelimpahan Fitoplankton. Journal of Management of Aquatic Resources, 2(2): 3845.

[6] Roman, M., F. K. Duan dan Suwari. 2016. Kontribusi Limbah Domestik Penduduk di Sekitar Sungai Biknoi Terhadap Kualitas Air Bendungan Biknoi Sebagai Sumber Baku Air Minum Serta Upaya Penangannya. Jurnal Bumi Lestari, 16(2): 155-162.

[7] Pohan, D. A. S., Budiyono dan Syafrudin. 2016. Analisis Kualitas Air Sungai Guna Menentukan Peruntukan Ditinjau dari Aspek Lingkungan. Jurnal Ilmu Lingkungan, 14(2): 63-71.

[8] Pamungkas, M. T. O. A. 2016. Studi Pencemaran Limbah Cair dengan Parameter $\mathrm{BOD}_{5}$ dan $\mathrm{pH}$ di Pasar Ikan Tradisional dan Pasar Modern di Kota Semarang. Jurnal Kesehatan Masyarakat, 4(2): 166-175.
[9] Mahyudin, Soemarno dan T. B. Prayogo. 2015. Analisis Kualitas Air dan Strategi Pengendalian Pencemaran Air Sungai Metro di Kota Kepajen Kabupaten Malang. J-PAL, 6(2): 105-114.

[10] Djoharam, V., E. Riani dan M. Yani. 2015. Analisis Kualitas Air dan Daya Tampung Beban Pencemaran Sungai Pesanggrahan di Wilayah Provinsi DKI Jakarta. Jurnal Pengelolaan Sumberdaya Alam dan Lingkungan, 8(1): 127-133.

[11] Asrini, N. K., I. W. S. Adnyana dan I. Y. Rai. 2017. Studi Analisis Kualitas Air di Daerah Aliran Sungai Pakerisan Provinsi Bali. Ecotrophic, 11(2): 101-107.

[12] Sugianti, Y dan L. P. Astuti. 2018. Respon Oksigen Terlarut Terhadap Pencemaran dan Pengaruhnya Terhadap Keberadaan Sumber Daya Ikan di Sungai Citarum. Jurnal Teknologi Lingkungan, 19(2): 203-212.

[13] Yudo, S dan N. I. Said. 2019. Kondisi Kualitas Air Sungai Surabaya Studi Kasus: Peningkatan Kualitas Air Baku PDAM Surabaya. Jurnal Teknologi Lingkungan, 20(1): 19-28.

[14] Rahayu, Y., I. Juwana dan D. Marganingrum. 2018. Kajian Perhitungan Beban Pencemaran Air Sungai di Daerah Aliran Sungai (DAS) Cikapundung dari Sektor Domestik. Jurnal Rekayasa Hijau, 1(2): 6171.

[15] Haeruddin, P. W. Purnomo dan S. Febrianto. 2019. Beban Pencemaran, Kapasitas Asimilasi dan Status Pencemaran Estuari Banjir Kanal Barat, Kota Semarang, Jawa Tengah. Journal of Natural Resources and Environmental Management. 9(3): 723-735.

[16] Guntur, G., A. T. Yanuar., S. H. J. Sari dan A. Kurniawan. 2017. Analisis Kualitas Perairan Berdasarkan Metode Indeks Pencemaran di Pesisir Timur Kota Surabaya. 
Jurnal Ilmu-ilmu Perairan, Pesisir dan Perikanan, 6(1): 81-89.

[17] Fachrul, M. F., A. Rinanti., D. Hendrawan dan A. Satriawan. 2016. Kajian Kualitas Air dan Keanekaragaman Jenis Fitoplankton di Perairan Waduk Pluit Jakarta Barat, 1(2): 109-120.

[18] Tamyiz, M. 2015. Perbandingan Rasio BOD/COD pada Area Tambak di Hulu dan Hilir Terhadap Biodegradabilitas Bahan Organik. Journal of Research and Technology. 1(1) : 9-15. 